\title{
Ablation treatment for Barrett oesophagus: what depth of tissue destruction is needed?
}

\author{
R Ackroyd, N J Brown, T J Stephenson, C J Stoddard, M W R Reed
}

\begin{abstract}
Aim-To establish the depth of Barrett's columnar epithelium and normal squamous oesophageal epithelium, in order to determine the depth of destruction required in ablation treatment for Barrett oesophagus.

Methods-Histological specimens from 100 cases of Barrett oesophagus and 100 samples of normal squamous oesophageal epithelium were studied. Using a system of multiple measurements until the change in cumulative mean values varied by less than $5 \%$, the overall mean and normal range of depth was calculated for each type of epithelium.

Results-Barrett columnar epithelium is minimally thicker (mean (SEM) 0.50 $(0.004) \mathrm{mm}$; range 0.39 to $0.59 \mathrm{~mm})$ than normal squamous epithelium $(0.49(0.003)$ $\mathrm{mm}$; 0.42 to $0.58 \mathrm{~mm}$ ), although this difference is probably too small to be of clinical relevance.

Conclusions-Although there are numerous clinical reports of various methods of ablation treatment for Barrett oesophagus, little attention has been paid to the depth of tissue destruction required. This is the first study to look specifically at this issue, and it provides information on the necessary depth of epithelial ablation. (f Clin Pathol 1999;52:509-512)
\end{abstract}

Keywords: Barrett oesophagus; ablation treatment; epithelial depth

Barrett oesophagus is an acquired condition in which the normal squamous mucosa of the lower oesophagus becomes replaced by a metaplastic columnar epithelium. ${ }^{1}$ Although the condition is often asymptomatic, its clinical importance is that it has a potential for malignant change. ${ }^{2-4}$ It is the major predisposing factor for oesophageal adenocarcinoma, the incidence of which has risen dramatically over the past two decades, such that it now represents up to $50 \%$ of all oesophageal malignancies. ${ }^{5}$

Standard treatment is aimed at reducing oesophageal acid exposure by either medical or surgical means. However, there is little evidence that this approach leads to any significant regression of Barrett epithelium. ${ }^{6-9}$ In view of this, attention has recently been given to ablation treatment to destroy the abnormal mucosa, which, in an anacid environment, may become replaced by normal squamous epithelium.

Various thermal ablation treatments have been considered, including laser photocoagulation, ${ }^{10}$ neodymium:yttrium-aluminium- garnet (Nd-YAG) laser, ${ }^{11}$ potassium titanyl phosphate (KTP) laser, ${ }^{12}$ and argon beam plasma coagulation (ABPC). ${ }^{13}$ An alternative approach is photodynamic therapy (PDT), a non-thermal technique which involves the administration of a photosensitising drug followed by the application of light to the affected area, to produce cell damage. The photosensitisers which have been used include haematoporphyrin derivative $(\mathrm{HpD})$, which has had some success in the treatment of patients with early adenocarcinomas in Barrett oesophagus, ${ }^{14}$ and more recently, the naturally occurring endogenous compound aminolaevulinic acid (ALA), which becomes converted to the photosensitive protoporphyrin IX (PpIX). ${ }^{15-17}$ The use of $\mathrm{HpD}$ is limited by prolonged skin photosensitivity and the risk of perforation or stricture formation, owing to the inability to control the depth of tissue damage. However, with ALA, a shorter period of systemic photosensitisation is produced, ${ }^{18}$ and an affinity for epithelial tissues is seen, allowing more selective mucosal necrosis, with less damage to underlying tissues and less risk of complications. ${ }^{19}$

In order to ablate Barrett epithelium successfully, adequate depth of tissue damage must be produced. It is particularly important to induce epithelial damage to a depth sufficient to destroy the deeper Barrett glands as well as the superficial epithelium, but desirable to avoid excessive damage to underlying muscle or surrounding normal tissue. There have been reports of residual buried glands beneath regenerated squamous epithelium following thermal laser ablation $^{12}$ and ALA-PDT, ${ }^{16}$ which may be the result of inadequate treatment depth. In none of the previous studies of ablation therapy for Barrett oesophagus has any consideration been given to the depth of the mucosa to be destroyed. There are no reports of any attempt to measure the depth of either Barrett columnar or normal squamous epithelium.

The aims of this study were to measure and compare the depth of normal squamous oesophageal epithelium and Barrett columnar oesophageal epithelium, to deduce the minimum depth of oesophageal mucosa required to be destroyed, to ablate Barrett mucosa.

\section{Methods}

The hospital histopathology records were searched using the Systematised Nomenclature of Medicine (SNOMED) classification of diseases, ${ }^{20}$ to identify both patients with Barrett oesophagus and those from whom oesophageal biopsies had been reported as normal squamous epithelium. The records were searched manually from 1991 to 1994 , but 


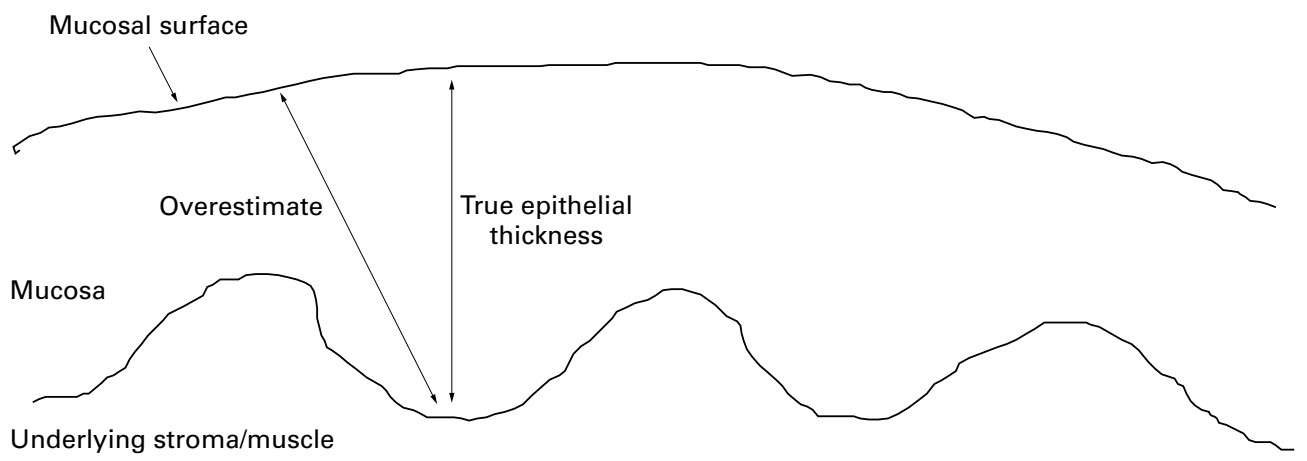

Figure 1 Measurement of the thickness of the oesophageal epithelium.

searching of the more recent records was facilitated by computerisation of the system. Ready mounted histological specimens were then obtained for a random selection of 100 cases of Barrett oesophagus and compared with a similar selection of 100 specimens of normal squamous oesophageal epithelium.

In order to calculate the epithelial thickness of a slide mounted histological specimen, multiple sections were measured using a calibrated microscope eyepiece graticule, which had previously been calibrated using a stage micrometer. Following calibration, multiple measurements were made of the epithelial thickness for each section. As sections through the epithelium may have been tangential rather than perpendicular, because of processing, these would result in overestimates of the thickness. Hence care was taken to ensure that all measurements were taken at right angles to the epithelial surface (fig 1). In all cases, the measurements taken were maximum mucosal thicknesses, in order to include the underlying muscularis mucosae and the glandular tissue associated with the Barrett epithelium.

The mean epithelial thickness for each specimen sectioned was calculated from the multiple measurements taken. However, at the onset it was not known how many measurements were needed before the calculated mean value could be regarded as a true representation of the epithelial thickness. This problem was overcome by calculating the cumulative mean of multiple measurements until the calculated value varied by less than a predetermined amount, which was set at less than $5 \%$ (fig 2).

Multiple sections were measured from 10 slide mounted specimens of normal squamous oesophageal epithelium and 10 of Barrett columnar epithelium. The cumulative means were calculated, and the results used to determine the number of measurements required before the cumulative mean varied consistently by less than $5 \%$.

Having determined the minimum number of measurements needed to assess accurately the true mean depth of the epithelium, 100 slide mounted samples of normal squamous epithelium and 100 samples of Barrett mucosa were assessed to determine the cumulative mean depth for each specimen. Finally, the overall mean depth of each type of oesophageal epithelium was calculated, and the normal range of depth was determined as that lying between the 5th and 95th centiles. Statistical analysis was by Student's $t$ test, with results considered significant at $\mathrm{p}<0.05$ (SPSS for Windows, version 6.0).

\section{Results}

It was found that six measurements were required so that the calculated cumulative mean varied by less than $5 \%$. A further 90 histological specimens of both normal squamous and Barrett columnar epithelium were therefore examined, making a total of 100 of each. Six random measurements of epithelial thickness were taken for each sample, from which

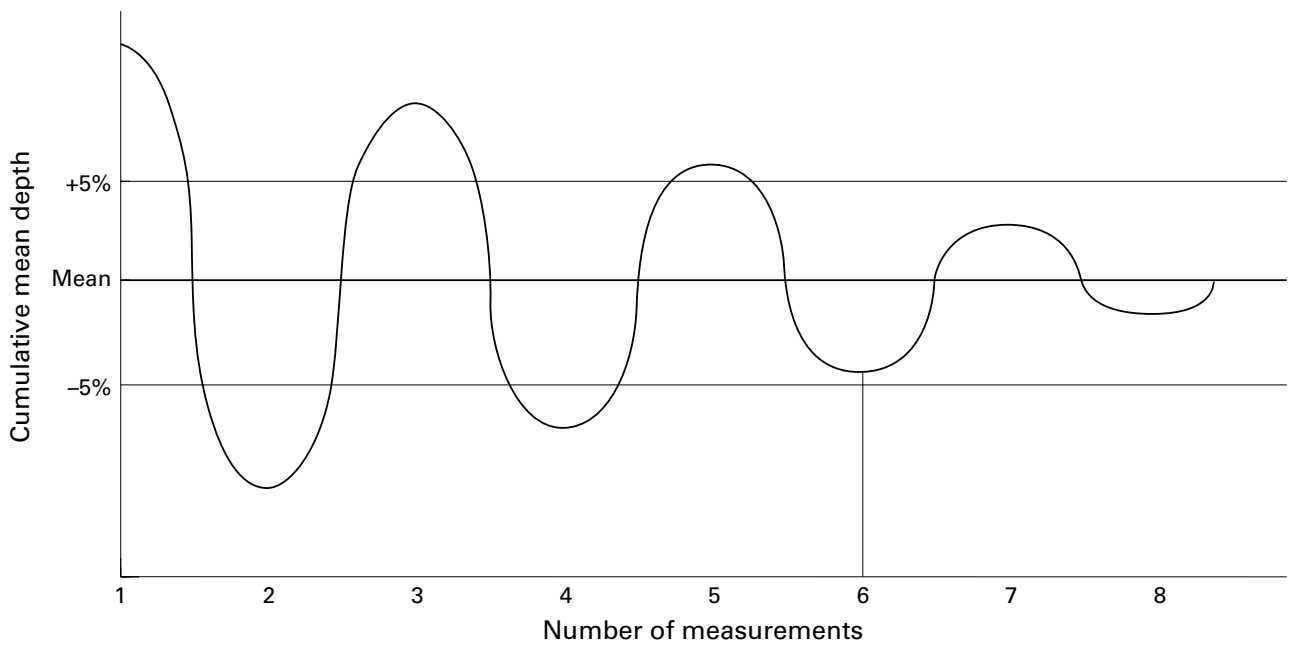

Figure 2 Calculation of the cumulative mean depth of the oesophageal epithelium. 
the mean thickness was then calculated. The overall mean epithelial thickness was subsequently calculated for each type of epithelium.

Barrett columnar epithelium is marginally thicker than normal squamous epithelium, with a mean (SEM) depth of $0.50(0.004) \mathrm{mm}$, as compared with $0.49(0.003) \mathrm{mm}$. The range of mean epithelial depths varied between 0.39 $\mathrm{mm}$ and $0.59 \mathrm{~mm}$ for the Barrett epithelium, and $0.42 \mathrm{~mm}$ to $0.58 \mathrm{~mm}$ for the normal squamous mucosa. If the normal range is considered to lie between the 5th and 95th centiles, then the normal range for the depth of Barrett epithelium is 0.43 to $0.57 \mathrm{~mm}$, and that for normal squamous epithelium is 0.44 to $0.54 \mathrm{~mm}(\mathrm{p}<0.05)$. However, although this difference is statistically significant, in clinical practice it is too small to be of relevance.

\section{Discussion}

Although successful epithelial ablation has been produced by various forms of ablation treatment, there are no reports of the measurement of the depth of either Barrett columnar mucosa or normal squamous epithelium. Incomplete epithelial ablation and partial regression has been reported following $\mathrm{PDT}^{21}$ possibly because of inadequate depth of tissue destruction. Equally, there have been reports of successful superficial epithelial ablation with aminolaevulinic acid induced PDT, but with sparing of the deeper glandular elements, resulting in squamous re-epithelialisation but with the persistence of underlying Barrett tissue, which may or may not constitute a continued risk of malignant change. ${ }^{16}$ Conversely, complications such as oesophageal perforation and stricture formation have been reported following both haematoporphyrin derivative induced PDT $^{14}$ and argon beam plasma coagulation, ${ }^{13}$ presumably because of an excessive depth of tissue necrosis. Measurement of the epithelial depth which requires ablation is therefore an important factor to consider.

In this study, the mean depth of 100 samples of Barrett mucosa was $0.5 \mathrm{~mm}$ and was less than $0.6 \mathrm{~mm}$ in all cases. However, it must be remembered that fixing of the samples produces shrinkage in the order of $10 \%$, followed by another $10 \%$ owing to processing, such that an overall shrinkage of approximately $20 \%$ occurs. ${ }^{22}$ If this is taken into account, the actual mean depth of Barrett mucosa is approximately $0.60 \mathrm{~mm}$ and was less than $0.70 \mathrm{~mm}$ in all cases. It appears, therefore, that ablation treatment should be aimed at producing tissue destruction to this depth in order to ensure complete Barrett eradication, including the deeper glands, while limiting the damage to the underlying structures.

Following PDT, the depth of tissue destruction is largely dependent upon the depth of tissue penetration by the activating light, although recent advances include specific photosensitisers, such as aminolaevulinic acid, which localise in the mucosa. The most commonly used wavelengths for clinical PDT are green $(514 \mathrm{~nm})$ or red $(630 \mathrm{~nm})$ light, which penetrate tissue to a depth of approximately $0.6 \mathrm{~mm}$ and $1.0 \mathrm{~mm}$ respectively. ${ }^{23}$ Both would, therefore, provide sufficient depth of tissue penetration in the vast majority of cases. It could be argued that red light may be better, as it would produce a more than adequate depth of tissue damage in all cases. However, green light may be safer, by providing adequate tissue penetration in all but a handful of cases, while avoiding the potential dangers of excessive depth of tissue destruction. With thermal ablation techniques, the depth of tissue penetration is dependent on the power output and duration of treatment, both of which can be controlled

In view of the rapidly increasing incidence of oesophageal adenocarcinoma, it is inevitable that reports of ablation treatments for Barrett oesophagus are becoming more common. However, this is the first study to address the issue of measuring the depth of the mucosa to be destroyed. Having established the depth of both Barrett columnar and normal squamous oesophageal epithelia in a large number of patients, further research is now needed to tailor the various forms of ablation treatment to produce the necessary depth of tissue destruction, while avoiding potential complications.

1 Naef AP, Savary M, Ozzello L. Columnar-lined lower esophagus: an acquired condition with malignant predispodenocarcinomas. I Thorac Cardiovasc Surg 1975;70:82634.

2 Cameron AJ, Ott BJ, Payne WS. The incidence of adenocarcinoma in columnar-lined (Barrett) esophagus. $N$ Engl f Med 1985;313:857-9.

3 Hameetman W, Tytgat GNJ, Houthoff HJ, et al. Barrett oesophagus: development of dysplasia and adenocarcioesophagus: development of dysplasia
noma. Gastroenterology 1989;96:1249-56.

4 Ovaska J, Miettinen M, Kivilaakso E. Adenocarcinoma arisOvaska J, Miettinen M, Kivilaakso E. Adenocarcinoma
ing in Barrett esophagus. Dig Dis Sci 1989;34:1336-9.

5 Tytgat GNJ. Esophagus: commentary. Curr Opin Gastroenterol 1995:11:337-8

6 Sampliner RE, Garewal HS, Fennerty MB, et al. Lack of impact of therapy on extent of Barrett esophagus in 67 patients. Dig Dis Sci 1990;35:93-6.

7 Igbal TH, Neumann CS, Cooper BT. Omeprazole treatment of patients with Barrett oesophagus [abstract]. Gut 1993;34:S19

8 Sampliner RE, Mackel C, Jennings D, et al. Effect of 12 months of a proton pump inhibitor (lansoprazole) on Barrett esophagus - a randomized trial [abstract]. Gastroenterology 1992;102:A517.

9 Bremner CG. Barrett oesophagus. In: Watson A and CelesBremner CG. Barrett oesophagus. In: Watson A and Celes-
tin LR, eds. Disorders of the oesophagus: advances and controversies. London: Pitman, 1984:94-104.

10 Berenson MM, Johnson TD, Markowitz NR, et al. Restoration of squamous mucosa after ablation of Barrett esophageal epithelium. Gastroenterology 1993;104:1686-91.

11 Sampliner RE, Hixson LJ, Fennerty B, et al. Regression of Barrett esophagus by laser ablation in an anacid environment. Dig Dis Sci 1993;38:365-8.

2 Barham CP, Jones RL, Biddlestone LR, et al. Photothermal laser ablation of Barrett oesophagus: endoscopic and histoogical evidence of squamous re-epithelialisation. Gut 1997;41:281-4.

13 Byrne JP, Armstrong GR, Attwood SEA. Endoscopic argon beam plasma coagulation in the restoration of squamous lining in Barrett oesophagus [abstract]. Endoscopy 1997;29: E33.

14 Overholt B, Panjehpour M, Tefftellar E, et al. Photodynamic therapy for treatment of early adenocarcinoma in Barrett therapy for treatment of early adenocarcinom

15 Regula J, MacRobert AJ, Gorchein A, et al. Photosensitization and photodynamic therapy of oesophageal, duodenal, and colorectal tumours using 5-aminolaevulinic acid nduced protoporphyrin IX - a pilot study. Gut 1995;36: $67-75$.

16 Barr H, Shepherd NA, Dix A, et al. Eradication of high-grade dysplasia in columnar-lined (Barrett) oesophgus by photodynamic therapy with endogenously generated protoporphyrin IX. Lancet 1996;348:584-5.

17 Gossner L, Stolte M, Sroka R, et al. Photodynamic ablation of high-grade dysplasia and early cancer in Barrett esophagus by means of 5 -aminolevulinic acid. Gastroenterology 1998;114:448-55.

18 Kennedy JC, Pottier RH. Endogenous protoporphyrin IX, a clinically useful photosensitizer for photodynamic therapy. f Photochem Photobiol B Biol 1992;14:275-92.

19 Bedwell J, MacRobert AJ, Phillips D, et al. Fluorescence distribution and photodynamic effect of ALA-induced PpIX in the DMH rat colonic tumour model. Br f Cancer 1992;65:818-24. 
20 Cote RA, Ed. Systematised nomenclature of medicine, 2nd ed. Skokie, Illinois: College of American Pathologists, 1982.

, Davis MF, Stephenson TJ, et al. Photodynamic therapy for Barrett oesophagus: a prospective randomised placebo-controlled trial [abstract]. Endoscopy 1997;29: 17.
22 Baker JR. Reactions of fixatives with proteins. 1. The visible effects. In: Baker JR, ed. Principles of biological microtechnique: a study of fixation and dyeing, 1st ed. Norwich: Fletcher and

23 Duck FA, ed. Physical properties of tissue: a comprehensive reference book. London: Academic Press, 1990.

\section{Fournal of Clinical Pathology - http://www.jclinpath.com}

Visitors to the world wide web can now access the fournal of Clinical Pathology either through the BMJ Publishing Group's home page (http://www.bmipg.com) or directly by using its individual URL (http://www.jclinpath.com). There they will find the following:

- Current contents list for the journal

- Contents lists of previous issues

- Members of the editorial board

- Information for subscribers

- Instructions for authors

- Details of reprint services.

A hotlink gives access to:

- BMJ Publishing Group home page

- British Medical Association web site

- Online books catalogue

- BMJ Publishing Group books.

The web site is at a preliminary stage and there are plans to develop it into a more sophisticated site. Suggestions from visitors about features they would like to see are welcomed. They can be left via the opening page of the BMJ Publishing Group site or, alternatively, via the journal page, through "about this site". 